\title{
PERANAN PENDAMPING SOSIAL DALAM PENANGANAN KASUS KEKERASAN TERHADAP ANAK PADA PUSAT PELAYANAN TERPADU PEMBERDAYAAN PEREMPUAN DAN ANAK (P2TP2A)
}

\author{
Maulida, M. Jamil Yusuf, Syaiful Indra \\ Program Studi Bimbingan dan Konseling Islam, Universitas Islam Negeri Ar Raniry \\ e-mail: syaiful.indra@ar-raniry.ac.id
}

\begin{abstract}
Abstrak. Kekerasan terhadap anak dapat diartikan sebagai setiap perbuatan terhadap anak yang berakibat timbulnya kesengsaraan atau penderitaan secara fisik, mental, seksual, psikilogis, termasuk penelantaran dan merendahkan martabat anak Dalam menjalankan kehidupannya, banyak diantara anak-anak yang mendapatkan haknya dan dapat tumbuh berkembang dengan baik, namun masih ada anak-anak yang tidak terpenuhi haknya sehingga mereka mengalami tindak kekerasan, maka untuk itu peneliti ingin meneliti lebih lanjut peranan pendamping sosial dalam penanganan kasus kekerasan terhadap anak. Penelitian ini bertujuan untuk mengetahui: (1) kompetensi pendamping sosial pada P2TP2A Kabupaten Aceh Selatan; (2) bentuk-bentuk kekerasan yang dihadapi oleh anak pada P2TP2A Kabupaten Aceh Selatan; (3) prosedur pendampingan sosial yang harus dilakukan oleh pendamping sosial dalam penanganan kasus kekerasan terhadap anak pada P2TP2A Kabupaten Aceh Selatan. penelitian ini merupakan penelitian lapangan (field research) yang bersifat kualitatif dengan menggunakan metode studi deskriptif untuk menggali informasi supaya dapat memenukan penjelasan mengenai peranan pendamping sosial dalam penanganan kasus KTA. Adapun teknik pengumpulan data dilakukan melalui observasi, wawancara dan studi dokumentasi. Sumber data dalam penelitian ini berjumlah dua orang dengan rincian satu orang kutua devisi pendidikan dan pelayanan pendampingan kasus dan satu orang pendamping sosial yang ada di P2TP2A Kabupaten Aceh Selatan ditentukan dengan menggunakan teknik purposive sampling. Adapun teknik pengolahan data dan analisis data dilakuakan dengan tiga langkah yaitu: data reduction, data display dan conclusion drawing/verification. Hasil penelitian menunjukan bahwa: (1) kompetensi pendamping sosial ditinjau dari segi jenjang pendidikan, standar kompetensi seorang pendamping sosial belum tercapai karena latar belakang pendidkan; (2) bentuk-bentuk kekerasan terhadap anak yang terjadi di P2TP2A adalah kekerasan fisik, psikis, seksual dan penelantaran, kasus inilah yang sering pendamping sosial damping; (3) Prosedur pendampingan yang di berikan oleh pihak P2TP2A terhadap korban/klien sudah berjalan dengan baik, dilihat dari prosedur dan layanan yang diberikan oleh pendamping sosial terhadap klien dalam menyelesaikan masalah yang dihadapi klien tersebut. Maka dari itu dapat dikatakan bahwasanya perenan pendamping sosial sangat dibutuhkan untuk membantu klien dalam menyelesaikan permasalahannya.
\end{abstract}

Kata kunci: peranan, pendamping sosial, kekerasan, anak, P2TP2A

\begin{abstract}
Violence against children can be interpreted as any act against a child which results in physical, mental, sexual, psychological, psychological suffering or suffering, including neglect and degrading of the child. but there are still children whose rights are not fulfilled so that they experience acts of violence, so for that researcher wants to further examine the role of social assistants in handling cases of violence against children. This study aims to determine: (1) the competency of social assistance in P2TP2A, South Aceh Regency; (2) forms of violence faced by children in P2TP2A, South Aceh Regency; (3) social assistance procedures that must be carried out by social assistants in handling cases of violence against children in P2TP2A, South Aceh Regency. This research is a qualitative field research using descriptive study methods to gather information in order to be able to find an
\end{abstract}


explanation of the role of social assistants in handling KTA cases. The data collection techniques are done through observation, interviews and documentation studies. The data source in this study amounted to two people with the details of one of the elders of the education division and case assistance services and one social assistant in P2TP2A, South Aceh District, was determined using purposive sampling technique. The data processing techniques and data analysis are done in three steps, namely: data reduction, data display and conclusion drawing / verification. The results showed that: (1) the competency of social assistants in terms of the level of education, the competency standards of a social companion had not been achieved because of the educational background; (2) forms of violence against children that occur in P2TP2A are physical, psychological, sexual abuse and neglect, this case is often the social companion of damping; (3) The accompanying procedure given by P2TP2 $A$ to the victim / client has been going well, judging from the procedures and services provided by the social assistant to the client in resolving the problems faced by the client. Therefore, it can be said that the role of social assistance is needed to help clients solve their problems.

Keywords: role, social companion, violence, children, P2TP2A

\section{PENDAHULUAN}

Pusat Pelayanan Terpadu Pemberdayaan Perempuan dan Anak (P2TP2A) dikatakan pusat pelayanan terpadu dikarnakan tindak kekerasan yang diterima bermacam-macam bentuk mulai dari kekersan fisik, psikis, seksual dan penelantaran, untuk menyelesaikan permasalahan tersebut maka setiap profesi yang bersangkutan dengan masalah yang dibawa ke P2TP2A akan ikut serta membantu menyelesaikan permasalahan yang dihadapi oleh anak sesuai profesi yang ditekuninya. P2TP2A didirikan untuk memberdayakan perempuan dan anak dari berbagai tindak kekerasan yang dialami oleh perempuan dan anak. Perhatian pemerintah terhadap kekersan diawali dengan adanya keprihatinan banyaknya perempuan mengalami kekerasan seksual yang terjadi pada tahun 1998.

Di dalam lembaga P2TP2A terdapat sumber daya manusia (SDM) yang berperan sebagai kepala lembaga, wakil, bendahara, sekertaris, administrasi, pendamping sosial, dan lain sebagainya. Mereka memiliki tugas dan tanggung jawanya masing-masing dalam membantu menyelesaikan permasalahan yang dihadapi oleh perempuan dan anak.

Petugas P2TP2A yang berperan penting dalam membantu menyelesaikan permasalahan terhadap perempuan dan anak adalah pendamping sosial yang memiliki berbagai profesi diantaranya, psikolog, doktor, perawat, pengacara dan lain sebagainya. Tugas utama pendamping sosial adalah untuk membantu menyelsaikan permasalahan perempuan dan anak.

Tindak kekerasan adalah permasalahan yang paling sering dialami oleh perempuan dan anak, yang bisa dilakukan oleh keluarga terdekat dan masyarakat sekitarnya. Tindak kekerasan memiliki berbagai macam bentuk yaitu kekerasan fisik, psikis, seksual, penelantaran, trafiking, eksploitasi, dan kekerasan lainnya (Kementerian Pemberdayaan Perempuan dan Perlindungan 
Anak Republik Indonesia: 77). Tindak kekerasan yang terjadi terhadap anak sangat berpengaruh besar tehadap tumbuh kembang anak nantinya.

Dalam menjalankan kehidupannya, banyak diantara mereka yang mendapatkan haknya dan dapat tumbuh berkembang dengan baik, namun masih ada anak-anak yang tidak terpenuhi haknya sehingga mereka mengalami tindak kekerasan yang dilakukan oleh orang terdekat dan masyarakat sekitarnya, sehingga menyebabkan anak mengalami trauma, gemetaran, keluhan fisik seperti rasa sakit di seluruh tubuh, gangguan tidur (insomnia), takut gelap, kecemasan yang berlebihan, merasa tidak aman, sering berpikiran negtif, dan lain sebagainya (Mufidah, 2008).

Kasus-kasus kekerasan terhadap anak yang ditangani oleh P2TP2A Kabupaten Aceh Selatan terhitung sejak Tahun 2013- Mei 2019 terdapat 198 kasus kekerasan terhadap anak yang terdiri dari kekerasan fisik, kekerasan psikis, diskriminasi, pelecehan seksual, dan penelantaran. Berdasarkan laporan keseluruhan P2TP2A Kabupaten Aceh Selatan dimana pada tahun 2013 terdapar 20 kasus, 2014 terdapat 47 kasus, tahun 2015 terdapat 26 kasus, ditahun 2016 terdapat 23 kasus, ditahun 2017 terdapat 35 kasus dan di tahun 2018 terdapat 39 kasus, di tahun 2019 sampai bulan Mei terdapat 8 kasus kekerasan terhadap anak (Laporan P2TP2A, 2019-2020).

Dampak kekerasan terhadap anak dapat mempengaruhi tumbuh kembang anak jika tidak ditindak lanjuti secepatnya. Maka dari itu mereka perlu didampingi untuk membantu menyelesaikan permasalahan yang dialaminya. Petugas P2TP2A yang berperan dalam membantu menyelesaikan permasalahan kekerasan terhadap tersebut adalah pendamping sosial, maka dari itu penulis ingin meneliti bagaimana peranan pendamping sosial untuk menyelesaikan permasalahan kekerasan yang dihadapi oleh anak yang dua tahun terakhir ini semakin meningkat. Dalam penelitian ini peneliti tidak meneliti kasus kekerasan yang dialami oleh perempuan, tetapi peneliti hanya meneliti kasus tindak kekerasan yang dialami oleh anak dikarnakan kasus tersebut yang banyak terjadi di Kabupaten Aceh Selatan.

\section{METODE}

Sesuai dengan judul penelitian, penulis menggunakan penelitian deskriptif. Tujuan dari penelitian deskriptif adalah untuk membuat deskripsi, gambaran atau lukisan secara sistematis factual dan akurat mengenai fakta-fakta, sifat-sifat serta hubungan antara fenomena yanf diselidiki (Moleong, 2006).

Adapun jenis penelitian yang dilakuan oleh peneliti adalah penelitian (Field Research). Penelitian Field Research atau penelitian lapangan dilakukan dilokasi suatu tempat yang sudah di pilih oleh peneliti, sebagai tempat untuk menyelidiki gejala objektif yang terjadi di lokasi tersebut serta dilakukan juga untuk laporan ilmiah (Fathoni, 2006). 
Penelitian ini dilakukan untuk menggali informasi agar dapat menemukan penjelasan mengenai peran psikolog sebagai pendamping soail dalam menangani kasus kekerasan terhadap anak pada P2TP2A Kabupaten Aceh Selatan.

Dengan demikian yang dimaksud penulis dalam penelitian ini yaitu penulis berusaha menggambarkan dan mendeskripsikan kembali apa yang dilihat, didengar dan yang dibaca dari hasil dokumentasi yang ada di Pusat Pelayanan Terpadu Pemberdayaan Perempuan dan Anak (P2TP2A) Kabupaten Aceh Selatan.

Lokasi yang dipakai oleh peneliti dalam penelitian ini adalah di secretariat Pusat Pelayanan Terpadu Perempuan dan Anak (P2TP2A) Kabupaten Aceh Selatan Jl. Tapak tuan-Meulaboh Desa Ujung Tanah Kecamatan Sama Dua, Aceh Selatan.

Lembaga tersebut menangani kasus-kasus kekerasan terhadap perempuan dan anak. Populasi penelitian ini adalah untuk mengetahui bagai mana peranan pendamping sosial dalam menangani kasus kekerasan terhadap anak pada P2TP2A Kabupaten Aceh Selatan.

Untuk menentukan dan memperoleh data yang diperlukan dalam penelitian skripsi ini penulis menggunakan sumber data primer dan sumber data sekunder.

\section{Data Primer}

2. Data Sekunder

Dalam penilitian ini subjek penilitian yang dijadikan sumber informasi dari 9 orang petugas hanya dua orang yang memenuhi kritria pendamping sosial orang yaitu :

1) Ketua devisi pendidikan dan pelayanan pendampingan kasus pada P2TP2A Kabupaten Aceh Selatan.

2) Devisi pelayanan pendampingan kasus pada P2TP2A Kabupaten Aceh Selatan.

Teknik pengumpulan data yang digunakan dalam penelitian ini adalah observasi, wawancara, dokumentasi.

1. Observasi

2. wawancara

3. Dokumentasi

Proses analisis data dalam penelitian ini dilakukan dengan menempuh beberapa langkah yang kemudian di simpulkan. Adapun langkah-langkah yang peneliti tempuh dalam menganalisis data dan pengolahan data adalah sebagai berikut:

1. Data Reduction (reduksi data) bearti merangkum, memilih hal-hal yang pokok, memfokuskan pada hal-hal yang penting, dicari tema dan polanya. 
2. Data Dislpay (penyajian data) adalah menyajikan data dalam bentuk uraian singkat, bagan, hubungan antar kategori dalam bentuk teks yang bersifat naratif

3. Conclusion drawing/verification yaitu penarikan kesimpulan dan verifikasi hasil penelitian yang telah didapatkan (Sugiyono, 2014).

\section{HASIL}

\section{Kompetensi pendamping sosial pada P2TP2A Kabupaten Aceh Selatan}

Adapun dari hasil penelitian yang terdapat dilapangan, peran pendamping sosial menurut Masliah (2020) yaitu:

"Peran pendamping sosial adalah menbantu korban yang mengalami tindak kekerasan, kami sebagai pendamping harus berjiwa sosial walaupun tidak melihat dari segi dana jadi kapanpun waktunya harus siap menpendampingi korban ”.

Menurut Masliah (2020): "selama bekerja dari tabun 2009 sampai sekarang. Semenjak beliau bekerja menjadi sekertaris dan sekarang telah berprofesi sebagai ketua devisi pendidikan dan pelayanan pendampingan kasus. Beliau telah menagani kurang lebih sebanyak 300 kasus, dengan berbagai bentuk. kekerasan terhadap perempuan dan anak serta kasus yang paling sering di tangani adalah kasus kekerasan terhadap anak".

Sedangkan menurut Murlidawati (2020): "selama bekerja di P2TP2A Kabupaten Aceh Selatan, pada tahun 2019 beliau menangani kasus kurang lebih sebanyak lima kasus kekerasan terbadap anak.". Dalam menangani berbagai kasus di P2TP2A seorang pendamping sosial harus bisa melakukan pembelaan terhadap klien agar kasus korban tersebut bisa terselesaikan. Namun apabila pendamping merasa tidak bisa melakukan pembela maka bisa di alihkan kepada orang lain yang lebih mengetahui tentang hukum seperti jaksa dan pengacara. Adapun pembelaan yang dilakukan oleh Masliah (2020) terhadap anak adalah:

"Kalau pembelaan pendampingan kepada anak dibawah umur seperti pelecehan seksual pada umur 10 tabun kebawah itu masih sangat labil, saat memberikan keterangan sewaktu berita acera perkara (BAP) di polres, maka kami selaku pendamping sosial yang ditugaskan untuk. mendampingi korban harus mengetahui bagaimana kasus korban tersebut secara rinci dan mencari informasi tentenag korban tersebut agar kami bisa melakukan pembelaan terbadap korban tersebut saat melakukan proses pada ranah bukum".

Namun sebelum masuk keranah hukum terlebih dahulu pendamping sosial harus melakukan proses mediasi, pendamping sosial harus mendengarkan dari kedua belah pihak supaya pendamping sosial mengetahui bagaimana sebenrnya kejadian atau masalah yang dialami oleh korban. Adapun mediasi menurut Masliah (2020) yaitu: "proses mediasinya dilakukan dengan musyawarah oleh pihak yang bersangkutan. Namun sebelum kasus ini dibawa ke Polres terlebih dabulu 
diselesaikan secara kekeluargaan dan disikapi juga oleh perangkat desa. Itu juga sesuai dengan kasus yang dialami dan keingginan korban”.

Adapun kemudahan dan motivasi yang diberikan oleh pendamping sosial kepada korban menurut Masliah (2020) dengan cara:

Kita bermain, mendekati dia, kita peluk, bercerita, jadi dengan adanya bubungan emosional dengan kita insya Allah dia akan merapat dan mau menceritakan apa yang dia alami. Namun apabila cara tersebut tidak bisa membuat korban terbuka biasanya kami mempunya cara lain seperti memberi makanan kesukaannya, bermain dan mainan seperti boneka dan apabila klien belum mau juga terbuka untuk menceritakan kejadian yang dialaminya biasanya kami akan memberikan motivasi, penguatan, pendekatn, meyakinkan dia dan menjelaskan cara-cara yang harus dilakukan kedepannya, kita rangkul dengan kasih sayang, dengan perhatian,. Apabila korban tidak mau menceritakan baru kami akan ke TKP atau pergi kerumah nya. supaya korban mau untuk. menceritakan ke kami kronologis kejadian yang dialaminya.

Tabel 1. Daftar nama pendamping social (Dokumen P2TP2A, 2019).

\begin{tabular}{lllll}
\hline NO & \multicolumn{1}{c}{ Nama } & \multicolumn{1}{c}{ Jenis Kelamin } & \multicolumn{1}{c}{ Jabatan } & Lama bekerja \\
\hline 1 & MS, Sarjana Hukum & Perempuan & $\begin{array}{l}\text { ketua devisi pendidikan } \\
\text { dan pelayanan } \\
\text { pendampingan kasus }\end{array}$ & 3 tahun \\
& & Devisi pelayanan kasus & 5 tahun \\
& $\begin{array}{l}\text { MD, Sarjana } \\
\text { Pendidikan }\end{array}$ & Perempuan & Delan & \\
\hline
\end{tabular}

Data tabel di atas menunjukan bahwa latar belakang pendidikan pendamping sosial di P2TP2A Kabupaten Aceh Sealatan bukanlah dari ranah pendidikan sosial, bimbingan konseling dan psikolog.

Berdasarkan hasil penelitian yang dialkukan, peneliti menemukan bahwa kompetensi yang di miliki oleh pendamping sosial di P2TP2A kabupaten Aceh selatan dari segi jenjang pendidikan belum mencapai standar kompetensi seorang pendamping sosial karena latar belakang pendidkan mereka bukalan dari ranah pendidikan sosial, bimbingan konseling dan psikolog. Namun mereka berusaha mendalami dan memahami bagaimana tugas dan kewajiban seorang pendamping sosial, sehingga mereka mampu mejalankan tugas tersebut dengan baik dan benar.

\section{Bentuk-bentuk Kekerasan yang Dihadapi oleh Anak Pada P2TP2A Kabupaten Aceh Selatan}

Berdasarkan hasil penelitian di lapangan, ditemukan adanya berbagai bentuk kekerasann terhadap anak sebagaimana penyataan Masliah (2020) yaitu: "pemerkosaan, pelecehan seksual, kekerasan fisik, kekerasan psikis, penelantaran anak, KDRT, sodomi, pencabulan dan traffaking juga ada”.

Tidak jauh berbeda dengan pernyataan yang dikemukakan oleh Murlidawati (2020), bentukbentuk kekerasan terhadap anak antara lain: "kekerasan fisik, kekerasan psikis, kekerasan seksual serta penelantaran anak". 
Kekerasan terhadap anak biasanya dilakukan oleh orang tua, keluarga terdekat, masyarakat sekitar, dan teman sebaya klien. Disebabkan mereka adalah orang-orang terdekat dengan klien sehingga orang lain beranggapan bahwa pelaku tindak kekerasan terhadap anak tidak mungkin dari orang-orang terdekat klien (Murlidawati, 2020).

a. Kekerasan Fisik

Berdasarkan hasil wawanacara dengan pendamping sosial di P2TP2A Kabupaten Aceh Selatan, jumlah kekerasan fisik terhadap anak beberapa tahun terakhir mencapai sekitar 90 kasus. Dan pelaku tindak kekerasan tersebut pada umumnya adalah keluarga terdekat. Korban biasanya berumur sekitar 17 tahun kebawah dengan berjenis kelamin laki-laki dan perempuan. kekerasan fisik biasanya terjadi di lingkungan keluarga dan diluar. Dengan faktor penyebabnya adalah broken home yang metidakibatkan kurangnya perhatian dari orang tua, pengaruh teman, sistem pengawasan dari orang tua yang pertama, kuncinya adalah iman (Masliah, 2020).

\section{b. Kekerasan Psikis}

Berdasarkan hasil wawanacara dengan pendamping sosial di P2TP2A Kabupaten Aceh Selatan, hampir semua bentuk tindak kekerasan terhadap anak adalah tindak kekerasan psikis di karnakan tindak kekerasan psikis itu adalah segala sesuatu perbuatan yang menekan seseorang yang metidakibatkan orang tersebut merasa takut, minder, dan lain sebagainya. Pelaku kekerasan psikis terhadap anak biasanya adalah orang terdekat dan teman-teman sebayanya. Kekersan psikis bisa saja di alami oleh anak perempuan dan anak laki-laki pada umur 8 sampai 17 tahun, faktor penyebab biasanya adalah kurang nya kasih sayang, memiliki musuh teman sebaya dan lain sebagainya (Masliah, 2020).

\section{c. Kekerasan Seksual}

Berdasarkan hasil wawanacara dengan pendamping sosial di P2TP2A Kabupaten Aceh Selatan yang di jelaskan oleh murlidawati (2020):

"Kekerasan seksual di P2TP2A memang ada terjadi, pelaku biasanya orang dewasa, terjadi pada anak umur tujuh sampai 17 tahun. Lingkungan tempat kejadian biasanya dilakukan di rumah serta ada beberapa di luar. Faktor penyebabnya adalah kurangnya perbatian orag tua terhadap anaknya.

\section{d. Penelantaran Anak}

Berdasarkan hasil wawancara dengan Pendamping Sosial di P2TP2A Kabupaten Aceh Selatan menurut Murlidawati (2020) kasus penelantaran anak ada cuma tidak terlalu banyak pelakunya pun orang tua sendiri kan karna akibat perceraian kan ceritanya, mungkin tidak dikirim 
nafkah untuk anak biasanya umur-umur ada yang masih SD sekitaran delapan tahunan ke atas, ada laki-laki ada perempuan dan tempat biasanya di fasilitas umum atau di pinggir-pinggir jalan.

Berikut ini adalah data bentuk-bentuk kasus kekerasan yang dialami oleh anak yang dibawa ke P2TP2A Kabupaten Aceh Selatan. bentuk-bentuk kekerasan yang dialami oleh anak bermacam-macam, mulai dari kasus kekerasan fisik, psikis, seksual dan penelataran.

Tabel 2. kasus kekerasan terhadap anak dari tahun 2013-Mei 2019 (P2TP2A, 2019-2020).

\begin{tabular}{|c|c|c|c|}
\hline $\mathrm{NO}$ & Tahun & Jenis Kasus & Jumlah \\
\hline \multirow[t]{2}{*}{1} & 2013 & Kekerasan fisik terhadap anak dan incest & 20 kasus \\
\hline & & Kekerasan fisik terhadap anak & 32 kasus \\
\hline \multirow[t]{2}{*}{2} & 2014 & Pelecehan seksual dan pemerkosaan terhadap anak & 15 kasus \\
\hline & & Kekerasan terhadap anak & 10 kasus \\
\hline \multirow[t]{2}{*}{3} & 2015 & Pencabulan terhadap anak & 6 kasus \\
\hline & & Kenakalan anak & 10 kasus \\
\hline \multirow[t]{2}{*}{4} & 2016 & Kekerasan terhadap anak & 13 kasus \\
\hline & & Kenakalan anak & 10 kasus \\
\hline \multirow[t]{3}{*}{5} & 2017 & Kekerasan terhadap anak & 22 kasus \\
\hline & & Kenakalan anak & 13 kasus \\
\hline & & Kekerasan terhadap anak & 28 kasus \\
\hline \multirow[t]{2}{*}{6} & 2018 & Kenakalan anak & 6 kasus \\
\hline & & Penelantaran anak & 5 kasus \\
\hline \multirow[t]{4}{*}{7} & 2019 Januari- & Pencabulan & 3 kasus \\
\hline & Mei & kenakalan Anak & 4 kasus \\
\hline & & Pernikahan Dini & 1 kasus \\
\hline & & $\begin{array}{l}\text { Total keseluruhan kasus kekerasan terhap anak dari tahun } \\
\text { 2013- mei } 2019\end{array}$ & 198 kasus \\
\hline
\end{tabular}

Dari tabel data di atas dapat dilihat bahwa kasus kekerasan terhadap anak di Kabupaten Aceh selatan dua tahun terakir ini semakin meningkat.

Berdasarkan hasil penelitian yang dilakukan, penulis menemukan bahwa bentuk-bentuk kekerasan terhadap anak yang terjadi adalah kekerasan fisik, psikis, seksual dan penelantaran. Pelaku yang melakukan kekerasan terhadap anak pada umumnya adalah orang dewasa dan orang yang dekat dengan klien tersebut, tempat kejadiannya pun tidak jauh dari lingkungan tempat tinggalnya dan bisa saja di tempat tinggal klien atau pelaku tersebut. Anak yang mengalami tindak kekerasan pada umumnya berusia 17 tahun kebawah, faktor penyebabnya dikarnakan kurangnya perhatian dari orang tua.

\section{Prosedur Pendampingan Sosial yang Dilakukan oleh Pendamping Sosial dalam Penanganan Kasus Kekerasan Terhadap Anak pada P2TP2A Kabupaten Aceh Selatan}

Berdasarkan hasil wawanacara dengan pendamping sosial di P2TP2A Kabupaten Aceh Selatan menurut Murlidawati (2020) prosedur pendampingan sosial yang dilakukan adalah:

"pertama kami memerima laporan setelah itu baru kami melakukan pendampingan kemana kasusnya akan dibawa. Misalnya ke polres atau keranah bukum yang ada di desa untuk bermusyawarah dulu dengan perangkat desa. Apabila tidak mendapat titik terang, kami akan 
mendiskusikan dengan korban tergantung korbannya mau dilanjutkean ke ranab bukum, kami teteap akan mendamping sampai kasusnya selesai”.

Tidak berbeda jauh dengan yang di sampaikan oleh murlidawati, masliah juga mengatakan bahwa prosedur pendampingan sosial yang di berikan adalah "prosedur dalam dalm arti kekerasan terhadap anak itukan laporan sudah kita terima jadi pihak kepolosi, apabila sudah sampai pada pihak kepolisian kan menelpon kita dan pihak P2TP2A akan datang kesana untuk pendampinga. Jadi kami sebagai pendamping akan berusaha untuk membuat si korban menceritakan kronologis kejadian tapi terkadang kekerasan terhadap anak ini yang trauma ada beberapa kasus yang trauma yg harus kita tunun kan kembali lagi psikolog dari profesi karna disini belum ada psikolog yg professional bukan professional tetapi yang titel nyan banyak gitu kalau ada pun di luar derah" (Masliah, 2020).

Dalam melakukan prosedur pendampingan apabila permasalahan tersebut belum selesai maka peendamping sosial akan menyediakan rumah aman untuk klien apabila klien merasa tidak aman atau tidak nyaman bila harus pulang ke lingkungan rumahnya, namun tidak semua kasus harus kami sediakan rumah aman tetapi tergantung bagaimana kasus tersebut dan permintaan klien, seperti yang dikatakan oleh marlidawati (2020):

"P2TP2 A aceh selatan memiliki rumah aman, kalau korban malu untuk pulang atau takut. Biasa nya, kami amankan dulu di rumah aman tetapi rumah aman di sini bukan rumah aman pada umumnya tetapi kami mencari rumah yang aman menurut si korban. mungkin dia nyaman di rumah siapa kita akan menempatkannya di situ.

Berdasarkan hasil penelitian yang dialkukan, peneliti menemukan bahwa prosedur pendampingan sosial yang diberikan oleh pendamping sudah terlaksana dengan baik karena mereka mau bekerja tanpa mengenal batasan waktu, yang mereka inginkan adalah kasus tersebut bisa cepat terselesaikan dan korban mendapatkan keadilan, namun dalam melakukan layanan pendampingan, tidak semua teknik mampu dikuasi oleh pendamping karna latar belakang pendidikan mereka bukan dari pendidikan profesi konselor atau psikolog.

\section{PEMBAHASAN}

\section{Kompetensi pendamping sosial pada P2TP2A Kabupaten Aceh Selatan}

Berdasarkan temuan peneliti yang terkait dengan kompetensi pendamping sosial pada P2TP2A Kabupaten Aceh Selatan dilihat dari segi jenjang pendidikan belum mencapai standar kompetensi seorang pendamping sosial karena latar belakang pendidkan mereka bukalan dari ranah pendidikan sosial, bimbingan kosneling dan psikolog. Namun mereka berusaha mendalami dan memahami bagaimana tugas dan kewajiban seorang pendamping sosial, sehingga mereka mampu mejalankan tugas tersebut dengan baik dan benar. 
Berdasarkan hasil pembahasan di atas dapat disimpulkan bahwa untuk menjadi seorang pendamping sosial/pekerja sosial seseorang harus menguasai tentang ilmu atau teori-teori mengemai pendampingan sosial untuk melakukan tugasnya dengan baik. Namun berbeda dengan hasil penelitian yang peneliti dapatkan di P2TP2A Kabupaten Aceh Selatan, dimana pada saat melakukan proses penelitian informan yang peneliti jumpai bukanlah seseorang yang memiliki latar belakang pendidikan sosial, bimbingan konseling atau psikolog, tetapi mereka berlatar belakng pendidikan sarjana hukum dan keguruan. Maka dari itu dapat dikatakan bahwa standar kompetensi/kemampuan apa saja yang harus dimiliki oleh pendamping sosial/pekerja sosial belum mencapai standar kompetensi seorang pendamping sosial/pekerja sosial.

\section{Bentuk-bentuk Kekerasan yang Dihadapi oleh Anak Pada P2TP2A Kabupaten Aceh Selatan.}

Berdasarkan hasil penelitian yang dilakukan, penulis menemukan bahwa bentuk-bentuk kekerasan terhadap anak ada kekerasan fisik, psikis, seksual dan penelantaran. Pelaku yang melakukan kekerasan terhadap anak pada umumnya adalah orang dewasa dan orang yang dekat dengan klien tersebut, tempat kejadiannya pun tidak jauh dari lingkungan tempat tinggalnya dan bisa saja di tempat tinggal klien atau pelaku tersebut. Anak yang mengalami tindak kekerasan pada umumnya berusia 17 tahun kebawah, faktor penyebabnya dikarnakan kurangnya perhatian dari orang tua.

Berdasrkan hasil pembahasan di atas peneliti menemukan bahwa bentuk-bentuk kekerasan terhadap anak itu ada empat yaitu: kekerasan fisik, psikis, seksual dan penelantaran. Faktor-faktor penyebabnya adalah faktor kemiskinan, pendidikan, sosial budaya, perilaku kasar dan faktor lingkungan yang tidak sehat. Hasil penelitian yang peneliti lakukan di P2TP2A Kabupaten Aceh Selatan juga terdapat bentuk-bentuk kekerasan terhadap anak seperti kekerasan fisik, psikis, seksual dan penelentaran. Peneliti juga mendapatkan hasil yang sama dengan teori bahwa faktor penyebab kekerasan terhadap anak itu kurangnya kasih sayang dan perhatian dari orang tua, faktor lingkungan dan pergaulan teman sebaya.

\section{Prosedur Pendampingan Sosial yang Harus Dilakukan oleh Pendamping Sosial dalam Penanganan Kasus Kekerasan Terhadap Anak pada P2TP2A Kabupaten Aceh Selatan.}

Berdasarkan hasil penelitian yang dialkukan, penulis menemukan bahwa Prosedur Pendampingan Sosial yang Harus Dilakukan oleh Pendamping Sosial dalam Penanganan Kasus Kekerasan Terhadap Anak pada P2TP2A Kabupaten Aceh Selatan, penulis menemukan bahwa prosedur pendampingan sosial yang diberikan oleh pendamping sudah terlaksana dengan baik karena mereka mau bekerja tanpa mengenal batasan waktu, yang mereka inginkan adalah kasus 
tersebut bisa cepat terselesaikan dan korban mendapatkan keadilan, namun dalam melakukan layanan pendampingan, tidak semua teknik mampu dikuasi oleh pendamping karna latar belakang pendidikan mereka bukan dari pendidikan profesi konselor atau psikolog.

Berdasarkan hasil pembahasan diatas dapat disimpulkan bahwa prosedur pendampinga sosial yang ada di P2TP2A Kabupaten Aceh Selatan sesuai dengan teori yang penulis gunakan, dimana proses pertama yang di terima adalah pengaduan selanjutnya akan di kembalikan kepada klien bagaima/kemana kaasus ini akan di selesaikan.

Setelah melakukan penelitian secara keseluruhan pada Pusat Pelayanan Terpadu Pemberdayaan Perempuan dan Anak dapat peneliti simpulkan bahwa peran pendamping sosial yang diterapkan/ dilakukan oleh pendamping sosial di P2TP2A Kabupaten Aceh Selatan sudah berjalan dengan baik, ada pun peran pendamping sosial adalah sebagai berikut:

1. Pembela (advocator)

2. Mediator (mediator)

3. Pemungkin (enaber)

4. Pemberi motivasi (motivator)

Dengan demikian, dapat dipastikan bahwa peranan pendamping sosial di P2TP2A Kabupaten Aceh Selatan sudah berjalan dengan baik, dilihat dari prosedur dan layanan yang diberikan oleh pendamping sosial terhadap klien dalam menyelesaikan masalah yang dihadapi klien tersebut. Maka dari itu dapat dikatakan bahwasanya perenan pendamping sosial sangat dibutuhkan untuk membantu klien dalam menyelesaikan permasalahannya.

\section{PENUTUP}

Berdasarkan hasil analisis yang telah dilakukan mengenai peranan pendamping sosial dalam penanganan kasus kekerasan terhadap anak pada pusat pelayanan terpadu pemberdayaan perempuan dan anak (P2TP2A) Kabupaten Aceh Selatan, dapat ditarik kesimpulan bahwa:

1. Keberhasilan pendamping sosial tidak terlepas dari usaha mereka untuk menyelesaikan permasalahan yang dihadapi oleh kliennya dan pengalaman yang mereka dapatkan dari berbagai kasus yang sudah pernah mereka tangani. Dari berbagai kasus yang sudah ditanagani mereka terus berusaha memperbaiki proses pendampingan sosial serta cara dalam menyelesaikan permasalahan klien nya, agar permasalahan klien nya tersebut bisa terselesaikan dengan cepat.

2. Secara keseluruhan bentuk-bentuk kekerasan yang dialami oleh anak pada P2TP2A Kabupaten Aceh Selatan adalah kekerasan fisik, psikis, seksual dan penelantaran. Pelaku yang melakukan 
kekerasan terhadap anak pada umumnya adalah orang dewasa dan orang yang dekat dengan klien tersebut, tempat kejadiannya pun tidak jauh dari lingkungan tempat tinggalnya dan bisa saja di tempat tinggal klien atau pelaku tersebut.

3. Prosedur pendampingan yang di berikan oleh pihak P2TP2A Kabupaten Aceh Selatan terhadap korban/klien sudah berjalan dengan baik. Maka dari itu dapat dikatakan bahwasanya perenan pendamping sosial sangat dibutuhkan untuk membantu klien dalam menyelesaikan permasalahannya.

\section{REFERENSI}

Abdurrahman Fathoni, Metode Penelitian dan Teknik Penyusunan Skripsi, Cet. Ke 1 (Jakarta: Rineka Cipta, 2006).

Abu Huraerah, Kekerasan Terbadap Anak, (Bandung: Nuansa Cendakia, 2018).

Departemen Pendidikan Nasional, Kamus Bahasa Indonesia, (Jakarta: Balai Pustaka, 1998).

Indra, S. (2016). Efektivitas Team Assisted Individualization untuk Mengurangi Prokrastinasi Akademik. Jurnal Edukasi: Jurnal Bimbingan Konseling, 1(2), 175-189

Indra, S., Rapono, M., \& Hayati, R. (2018). Efektivitas team Assisted Individualization untuk Meningkatkan Pemahaman pada Mata Kuliah Model-Model Konseling. Jurnal Penelitian Pendidikan Sosial Humaniora, 2(1), 141-146

Julia, H., Jarnawi, J., \& Indra, S. (2019). Pola Pengasuhan Pada Konteks Kematangan Emosional Ibu Single Parent. Indonesian Journal of Counseling and Development, 1(1), 31-49

Kementerian Pemberdayaan Perempuan Dan Perlindungan Anak Republik Indonesia, Peraturan Menteri Negara Pemberdayaan Perempuan Dan Perlindungan Anak. Republic Indonesia Nomor 01 Tabun 2010 Tentang Standar Pelayanan Minimal (SPM) Bidang Layanan Terpadu Bagi Perempuan Dan Anak Korban Kekerasan, (Jakarta: Catatan Kementerian Sosial, 2010).

Kementerian Pemberdayaan Perempuan Dan Perlindungan Anak Republik Indonesia, Buku Pegangan Fasilitas Peningkatan Kapasitas Pengelola P2TP2A dan Forum Koordinasi Lembaga Layanan Bagi Badan Pemberdayaan Perempuan dan Koordinator Wilayah, Jakarta: Catatan Kementerian Sosial, 2015).

Keputusan Menteri Sosial No.10/HUK/2007. Laporan Keseluruhan P2TP2A Kabupaten Aceh Selatan.

Lexi J. Meleong, Metodologi Penelitian Kualitatif, (Bandung: Remaja Rosdakarya, 2006). Mufidah, Psikologi Keluarga Islam Berwawasan Gender, (Malang: UIN Malang Press, 2008).

Pohan, RA Pohan., \& Indra, S. (2020) Efektivitas Layanan Bimbingan Kelompok dalam

Meningkatkan Kegiatan Merespon Pembelajaran. Islamic Counseling: Jurnal Bimbingan Konseling Islam, 4(1), 17-30

Sugeng Pujileksono, Perundang-undangan Sosial dan Pekerjaan Sosial Perspektif Pemenuban Keadilan Dan Kesejabteraan Sosial Masyarakat), ( Malang: Setara Press, 2016).

Sugiyono, Metode Penelitian Kuantitatif Kualitatif, R®D (Bandung: Alfabeta, 2013).

Sugiyono, Metode Penelitian Kuantitatif, Kualitatif, R $\odot D$, Cet Ke 21 (Bandung: Alfabeta, 2014).

Sujadi, E. (2018). Perbedaan Locus of Control ditinjau dari Etnis. Jurnal Bimbingan Dan Konseling Terapan, 2(2), 128-138. https://doi.org/10.30598/jbkt.v2i2.371

Sujadi, E. (2019). Penerapan Play Therapy dengan Menggunakan Permainan Tradisional untuk Meningkatkan Keterampilan Sosio Emosional. Jurnal Bimbingan Dan Konseling Terapan, 3(1), 14-24. https://doi.org/https://doi.org/10.30598/jbkt.v3i1.892

Sujadi, Eko. (2018). Kode Etik Profesi Konseling Serta Permasalahan dalam Penerapannya. Tarbawi : Jurnal Ilmu Pendidikan, 14(2), 69-77. https://doi.org/10.32939/tarbawi.v14i2.298 
Sujadi, Eko, \& Meditamar, M. O. (2020). Perbedaan Locus of Control ditinjau dari Perspektif Agama pada Siswa SMA. Analitika: Jurnal Magister Psikologi UMA, 12(1), 44-54. https://doi.org/http://dx.doi.org/analitika.v11i1.3506

Sujadi, Eko, Yusuf, A. M., \& Marjohan, M. (2016). Hubungan antara Locus Of Control dan Efektivitas Komunikasi antar Pribadi dengan Problem Focused Coping. Konselor, 5(1), 2531. https://doi.org/https://doi.org/10.24036/02016516490-0-00

Suzie Sugijokanto, Cengah Kekerasan Pada Anak, (Jakarta: PT Gramedia, 2014).

Undang-Undang RI Nomor 11 tahun 2009 Tentang Kesejahteraan Sosial. Pada pasal 1 ayat 4.

UndangUndang RI Nomor 23 Tahun 2002 Tentang Perlindungan Anak pada pasal 1 ayat 14.

UU Republik Indonesia Nomor 35 Tahun 2014 tentang perubahan atas UU Nomor 23 Tahun 2002 tentang perlindungan anak pasal 1, butir 1 dan 12. 